\title{
PERANCANGAN SISTEM INFORMASI PENCATATAN GIZI BALITA DENGAN METODE FORWARD CHAINING
}

\author{
Retno Sari, M.Kom ${ }^{1}$, Ratih Yulia Hayuningtyas, M.Kom² \\ ${ }^{1}$ Teknik Informatika,Sekolah Tinggi Manajemen Informatika dan Komputer Nusa Mandiri \\ Indonesia \\ ${ }^{2}$ Teknik Informatika, Sekolah Tinggi Manajemen Informatika dan Komputer Nusa Mandiri \\ Indonesia \\ ${ }^{1}$ retno.rnr@nusamandiri.ac.id, ${ }^{2}$ ratih.ryl@nusamandiri.ac.id
}

\begin{abstract}
Posyandu is a health unit in the community to serve the health of mothers and toddlers. Every month the Posyandu conducts weighing of children under five to record data on age, weight and height which are used as indicators to see nutritional status, height and weight of children under five. This recording is used to see toddlers who are still below the red line using anthropometric standards for nutritional assessments. Anthropometric assessment uses Zscore calculations and sees threshold categories to see nutrition in toddlers. To overcome this problem, the purpose of this study is to create an information system for recording nutrition for toddlers using the Forward Chaining method developed with the SDLC model to assist decision making in taking actions on toddlers who are still below the red line. The results of this study are to quickly display the results of the nutritional status of children under five and well organized nutritional status assessment reports.
\end{abstract}

Keywords:Information Systems; Toddler Nutrition Recording; Forward Chaining

\begin{abstract}
Abstrak
Posyandu merupakan unit kesehatan yang berada dimasyarakat untuk melayani kesehatan ibu dan balita. Setiap bulan posyandu mengadakan penimbangan terhadap balita untuk mencatat data umur, berat badan dan tinggi badan yang dijadikan indikator untuk melihat status gizi, tinggi badanm dan berat badan pada balita. Pencatatan ini digunakan untuk melihat balita yang masih berada di bawah garis merah menggunakan standar Antropometri peniliaian gizi. Penilaian dengan antropometri menggunakan perhitungan Zscore dan melihat kategori ambang batas untuk melihat gizi pada balita. Untuk mengatasi permasalahan ini, maka tujuan penelitian ini dengan membuat suatu sistem informasi pencatatan gizi balita menggunakan metode Forward Chaining yang dikembangkan dengan model SDLC untukmembantu pengambilan keputusan dalam melakukan tindakan pada balita yang masih di bawah garis merah. Hasil dari penelitian ini adalah dapat dengan cepat menampilkan hasil status gizi balita dan terorganisir dengan baik laporan penilaian status gizi.
\end{abstract}

Kata Kunci: Sistem Informasi; Pencatatan Gizi Balita; Forward Chaining 


\section{Introduction}

Gizi dapat dijadikan salah satu faktor yang penting dalam tumbuh kembang anak(Firmansyah, Risanty, \& Mujiastuti, 2002). Persentase kasus balita dengan status gizi buruk bawah garis merah (BGM) atau kurus di Provinsi DKI Jakarta pada tahun 2017 terjadi peningkatan dibandingkan dengan tahun 2016 sebesar 2,27\%, pada tahun 2018 terjadi penurunan hingga mencapai $0,6 \%$ berdasarkan hasil penimbangan di puskesmas maupun di posyandu(Jakarta, 2018).

Posyandu merupakan usaha kesehatan berbasis masyarakat dengan kegiatan program prioritasnya yaitu perbaikan gizi yang dilaksanakan oleh, dari, dan bersama masyarakat untuk mendapatkan pelayanan kesehatan bagi ibu, bayi anak balita (Jakarta, 2018). Anak balita yaitu anak yang berumur 0 sampai dengan 59 bulan.

Posyandu Rw. 03 kelurahan penggangsaan melakukan penimbangan balita setiap bulannya. Penimbangan dilakukan dengan cara mencatat umur, mencatat berat badan, dan mencatat tinggi badan. Data ini dijadikan sebagai acuan melihat status gizi pada balita.

Antropometri merupakan metode penilaian status gizi yang paling sering digunakansebagai indikator status gizi (Fitri, 2017). Status gizi pada balita dapat diukur berdasarkan umur, berat badan (BB) dan tinggi badan (TB). Variabel umur, BB dan TB disajikan dalam bentuk tiga indikator yaitu berat badan menurut umur $(\mathrm{BB} / \mathrm{U})$, tinggi badan menurut umur $(\mathrm{TB} / \mathrm{U})$ dan berat badan menurut tinggi badan (BB/TB)(Sunarya, Wirawan, \& Sukendry, 2017). Balita yang mengalami masalah status gizi dapat dilihat dari kartu menuju sehat (KMS) yaitu balita di bawah garis merah (BGM) (Ratnawati, Probowati, Prihatini, Pawiono, \& Pujiani, 2020).

Hingga saat ini penanggulangan gizi buruk belum dapat teratasi dengan baik di Indonesia dikarenakan masalah gizi buruk mempunyai dimensi yang sangat luas (Simorangkir, Kahar, \& Simatupang, 2015). Salah satu faktor yang mempengaruhi status gizi anak yaitu faktor ekonomi keluarga yang berdampak pada pola makan dan kecukupan gizi anak (Devi, 2010).

Sudah dilakukan penelitian sebelumnya mengenai pemetaan status gizi balita dalam mendukung keberhasilan pencapaian millenium development goals (MDGs), menggunakan metode cross-sectional dan pengembangan sistem informasi menggunakan SDLC yang menampilkan informasi gizi (Setyowati \& Astuti, 2015).

Penelitian lainnya yaitu rancang bangun sistem informasi rekam medik posyandu berbasis komputasi awan menggunakan metode MVC (model, view, controller) dengan melakukan beberapa pengujian yaitu 
black box, white box, dan usability. Pada penelitian ini menghasilkan informasi rekam medik posyandu (Effendi, Roslidar, \& Dawood, 2015).

Pada tahun 2016 dilakukan penelitian penerapan sistem informasi posyandu Mawar Kelurahan Simpang Empat yang bertujuan untuk membuat aplikasi yang membantu dan mempermudah kader posyandu dalam pencatatan dan menentukan status gizi balita (Pratama, 2016).

Tinjauan terkait lainnya yaitu sistem informasi pemantauan tumbuh kembang balita pada posyandu menggunakan metode Z-Score berbasis web, penelitian ini menghasilkan status gizi balita (Nuraeni, Wajhillah, \& Pribadi, 2014).

Untuk mendukung program kementrian kesehatan dalam mengurangi balita yang masih di bawah garis merah, penelitian ini mengusulkan untuk membangun sistem informasi pencatatan gizi balita menggunakan metode forward chaining dengan model SDLC untuk memprediksi balita yang masih mengalami gizi kurang dalam mengupayakan pengendalian balita di bawah garis merah. Sistem informasi ini bertujuan untuk membantu pengambilan keputusan dalam melakukan tindakan pada balita yang masih di bawah garis merah, karena metode forward chaining menghubungkan suatu masalah dengan solusi atau mencari kesimpulan dengan proses per tahap (Shofi, Wardhani, \& Anisa, 2016).

\section{Materials and Methods}

Sistem pakar merupakan salah satu kecerdasan buatan yang dimiliki oleh seorang ahli untuk menyelesaikan suatu masalah (Sunarya et al., 2017).Sistem pakar telah banyak digunakan untuk memecahkan masalah seperti dibidang kesehatan, penjadwalan, desain dan sebagainya (Astuti, Sutarno, \& Rasim, 2017).

Basis pengetahuan dibagi menjadi dua bagian yaitu fakta dan kesimpulan. Fakta dikelompokkan menjadi lebih spesifik yang kemudian dikelompokkan menjadi sebuah kesimpulan (Mulyani, Erwandi, \& Aryanti, 2015). Mencocokan basis pengetahuan menggunakan mesin inferensi. Mesin inferensi merupakan sumber dari sebuah sistem pakar yang dikenal dengan control structure (Rosnelly, 2011). Mesin inferensi terdiri dari dua teknik yaitu pelacakan kebelakang (Backward chaining) dan pelacakan ke depan (forward chaining) (Hayadi, 2015).

Forward Chaining dapat dikatakan inferensi yang menghubungkan suatu masalah dengan solusi atau mencari kesimpulan dengan proses per tahap (Shofi, Wardhani, \& Anisa, 2016). Teknik perncarian pada forward chaining dengan 
mencocokan fakta-fakta dan bagian IF dari rules IF_THEN (Hayadi, 2015).

Kerangka pemikiran pada penelitian ini dapat dilihat pada gambar 1 .

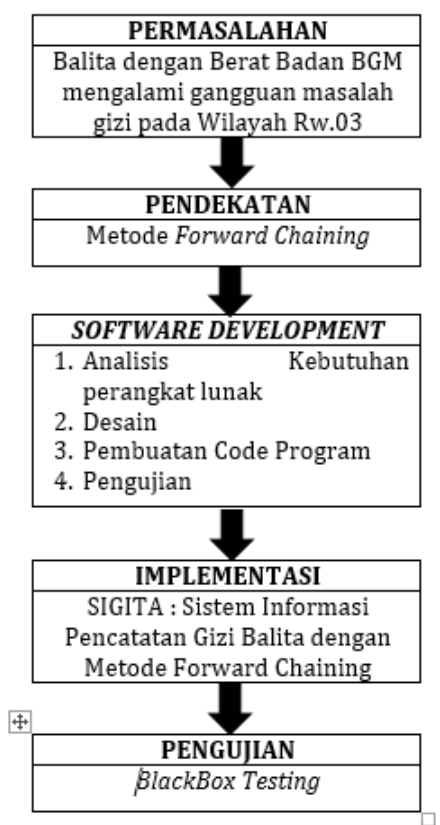

Gambar 1. Kerangka pemikiran

Pendekatan yang digunakan pada penelitian ini yaitu forward chaining, berikut adalah gambar ilustrasi forward chaining.

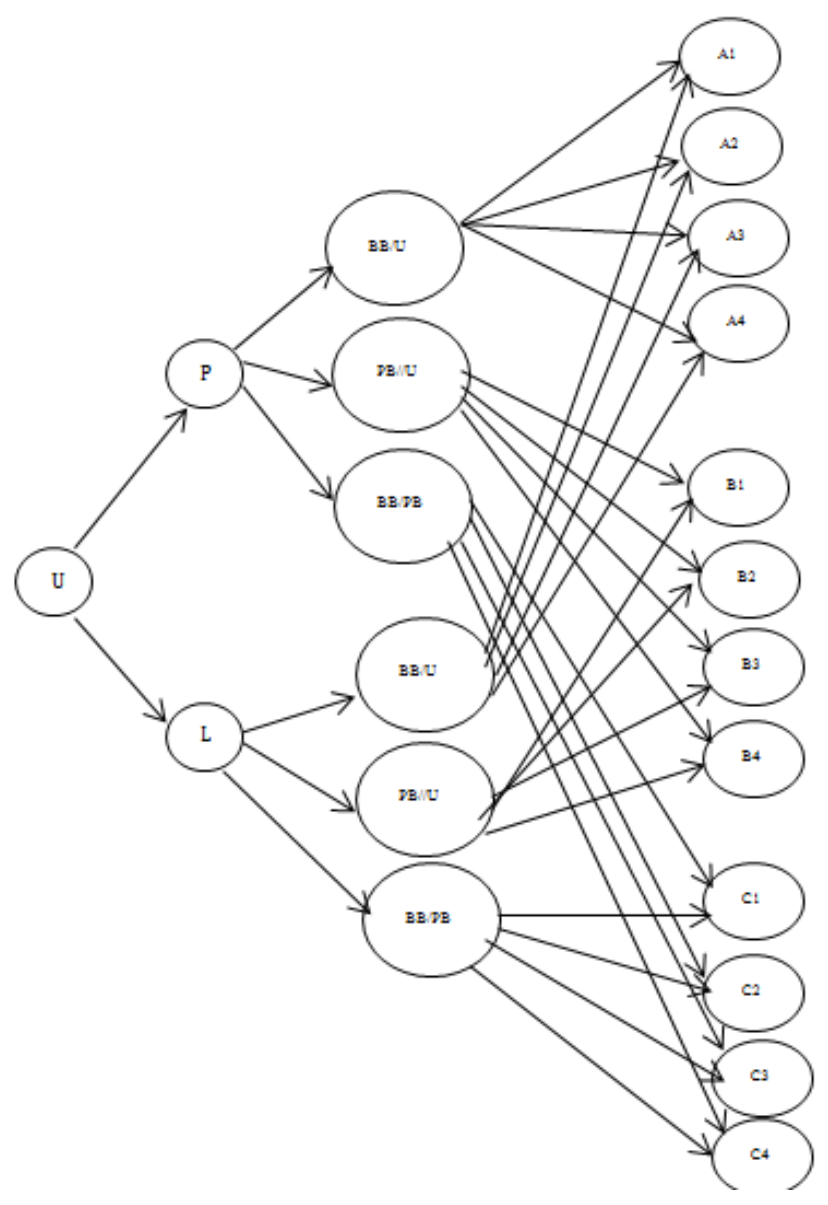

Gambar 2. Aturan Forward Chaining

Keterangan:

U : Umur

$\mathrm{P} \quad$ : Perempuan

L : Laki-Laki

BB/U : Berat badan menurut umur

PB/U : Panjang badan menurut umur

$\mathrm{BB} / \mathrm{PB}$ : Berat badan menurut panjang badan

A1-A4 : Hasil gizi (buruk, kurang, baik, lebih)

B1-B4 : Hasil tinggi (sangat pendek, pendek, normal, tinggi)

C1-C4 : Hasil berat badan (sangat kurus, kurus, normal, gemuk)

Untuk melihat hasil pertumbuhan balita 
mengenai gizi, dapat dilihat nilai ambang batas. Kategori dan ambang batas status gizi anak berdasarkan indeks dapat dilihat pada tabel dibawah ini.

Tabel 1. Ambang Batas

\begin{tabular}{|c|c|c|}
\hline Indeks & $\begin{array}{l}\text { Kategori } \\
\text { Status Gizi }\end{array}$ & $\begin{array}{c}\text { Ambang Batas } \\
\text { (Z-Score) }\end{array}$ \\
\hline \multirow{4}{*}{$\begin{array}{l}\text { BB/U } \\
\text { Anak Umur } \\
\text { 0-60 Bulan }\end{array}$} & Gizi Buruk & $<-3 \mathrm{SD}$ \\
\hline & Gizi Kurang & $-3 \mathrm{SD}$ s/d <-2SD \\
\hline & Gizi Baik & $-2 \mathrm{SD}$ s/d 2SD \\
\hline & Gizi Lebih & $>2 \mathrm{SD}$ \\
\hline \multirow{2}{*}{$\begin{array}{l}(\mathrm{PB} / \mathrm{U}) \text { atau } \\
(\mathrm{TB} / \mathrm{U})\end{array}$} & Sangat Pendek & $<-3 \mathrm{SD}$ \\
\hline & Pendek & $-3 \mathrm{SD}$ s/d <-2SD \\
\hline \multirow{2}{*}{$\begin{array}{l}\text { Anak Umur } \\
\text { 0-60 Bulan }\end{array}$} & Normal & $-2 \mathrm{SD}$ s/d 2SD \\
\hline & Tinggi & $>2 \mathrm{SD}$ \\
\hline \multirow{3}{*}{$\begin{array}{l}(\mathrm{BB} / \mathrm{PB}) \\
\text { atau } \\
(\mathrm{BB} / \mathrm{TB})\end{array}$} & Sangat Kurus & $<-3 S D$ \\
\hline & Kurus & $-3 \mathrm{SD} s / \mathrm{d}<-2 \mathrm{SD}$ \\
\hline & Normal & $-2 \mathrm{SD}$ s/d 2SD \\
\hline Umur $\quad 0-60$ & Gemuk & $>2 \mathrm{SD}$ \\
\hline Bulan & & \\
\hline
\end{tabular}

Sumber : (Kemenkes, 2011)

Berikut adalah aturan forward chaining untuk proses penentuan hasil gizi dapat dilihat pada tabel dibawah ini.

Tabel 2. Aturan Forward Chaining

\begin{tabular}{ll}
\hline No & \multicolumn{2}{c}{ Rule } \\
\hline 1 & IF JK $=$ LakiLaki AND Umur $=30$ AND \\
& Zscore $<-3$ SD Then A1 \\
\hline 2 & IF JK $=$ LakiLaki AND Umur $=30$ AND \\
& Zscore $<-3$ SD \&\& $<-2$ SD Then A2 \\
\hline 3 & IF JK $=$ LakiLaki AND Umur $=30$ AND \\
& Zscore $=$-2SD \&\& 2SD Then A3 \\
\hline 4 & IF JK $=$ LakiLaki AND Umur $=30$ AND \\
& Zscore $>$ 2SD Then A4
\end{tabular}

Metode Zscore digunakan untuk menentukan status gizi balita dengan rumus (Nuraeni et al., 2014)

$$
\text { Zscore }=\frac{N I S-N M B R}{N S B R}(1)
$$

Keterangan :

NIS : Nilai Individual Subjek

NMBR: Nilai Median Buku Rujukan

NSBR : Nilai Simpang Baku Rujukan

Dari rule dan skenario dapat Dilakukan percobaan dengan fakta seorang anak lakilaki berumur 24 bulan dengan berat badan $8 \mathrm{~kg}$, dan panjang badan $74 \mathrm{~cm}$. Dari data antoprometri didapat data sebagai berikut:

\begin{tabular}{|c|c|c|c|c|c|c|c|}
\hline $\begin{array}{c}\text { Umur } \\
\text { (Bulan) }\end{array}$ & -3SD & -2SD & -1SD & Median & 1 SD & 2 SD & 3SD \\
\hline 24 & 8,6 & 9,7 & 10,8 & 12,2 & 13,6 & 15,3 & 17,1 \\
\hline
\end{tabular}

Gambar 3. Antoprometri

Perhitungan Zscore sebagai berikut:

Zscore $=\frac{8-12,2}{12,2-10,8}=-3$

Dari perhitungan di atas didapatkan nilai ambang batas $\mathrm{BB} / \mathrm{U}$ yaitu -3 dengan kategori status gizi kurang, PB/U yaitu 4,37 dengan kategori sangat pendek dan BB/PB yaitu -1,86 dengan kategori berat badan normal.

\section{Results and Discussion}

Pada penelitian ini dilakukan pengembangan sistem menggunakan metode SDLC. Model SDLC menyediakan 
pendekatan alur hidup perangkat lunak secara sekuensial atau terurut dimulai dari analisis, desain, pengkodean, pengujian, dan tahap pendukung (Sukamto \& Shalahuddin, 2018). Berikut adalah tahapan SDLC:

a. Analisis kebutuhan perangkat lunak

b. Penggunasistem memiliki kebutuhan dan interaksi dengan sistem yang berbeda, seperti berikut:

1) Skenario Kebutuhan User
a) Mengelola data balita
b) Mengelola data user
c) Mengelola data orang tua
d) Mengelola data jenis kelamin
e) Mengelola data $\mathrm{BB} / \mathrm{TB}$
f) Mengelola data berat badan
g) Mengelola data tinggi badan
h) Mencatat data status gizi
i) Mengelola laporan
j) Melakukan ganti password
k) Mengelola artikel

2) Skenario Kebutuhan Orang Tua

a) Melihat artikel

b) Melihat data diri

c) Melakukan ganti password

d) Melihat rekam status gizi

Diagram usecase user dapat dilihat pada gambar 4 dan usecase diagram orangtua pada gambar 5 .

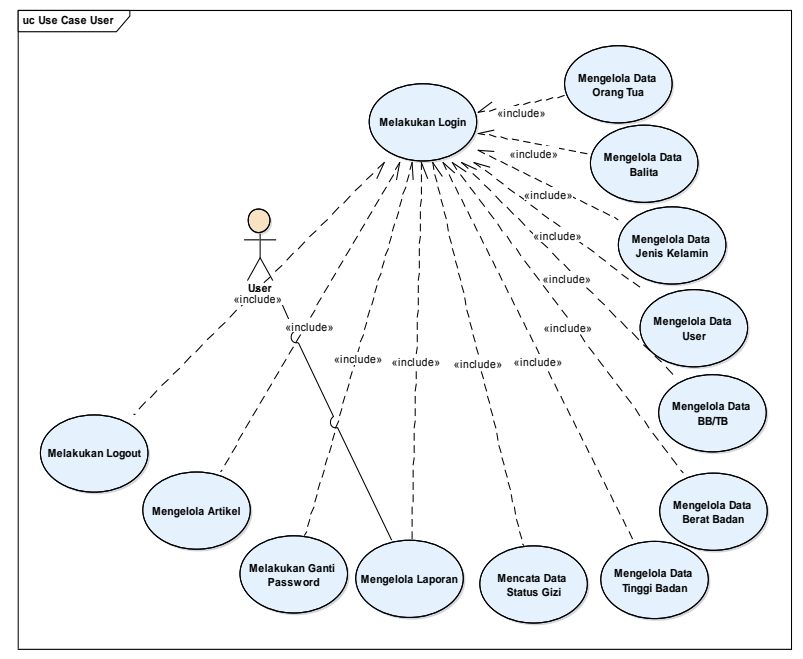

Gambar 4. Diagram Use case user

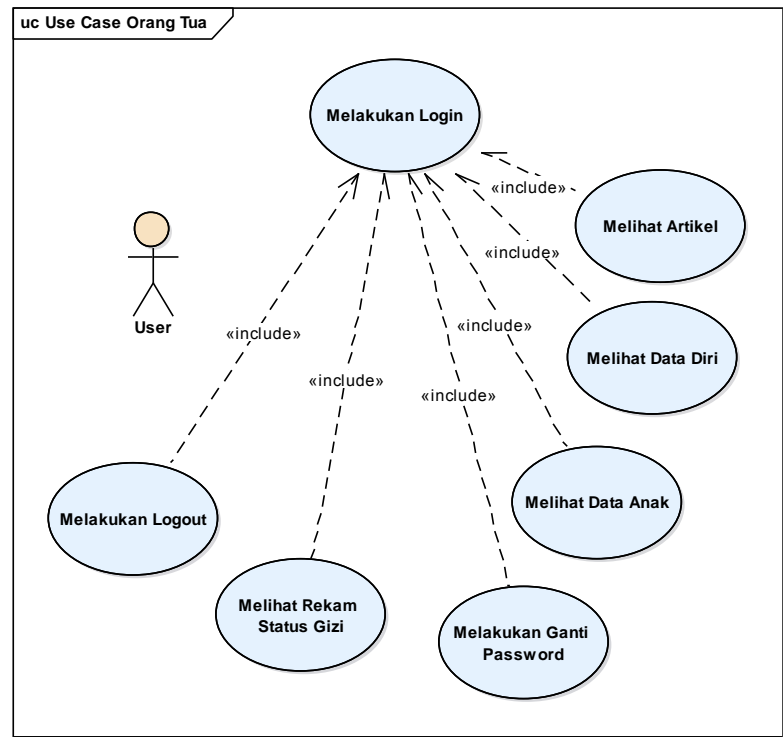

Gambar 5. Diagram Use case Orang Tua

c. Desain

Pada tahapan ini dilakukan translasi kebutuhan perangkat lunak dari tahap analisi kebutuhan ke representasi desain agar dapat diimplementasikan menjadi program (Sukamto \& Shalahuddin, 2018). Berikut adalah gambar ERD pada penelitian ini: 


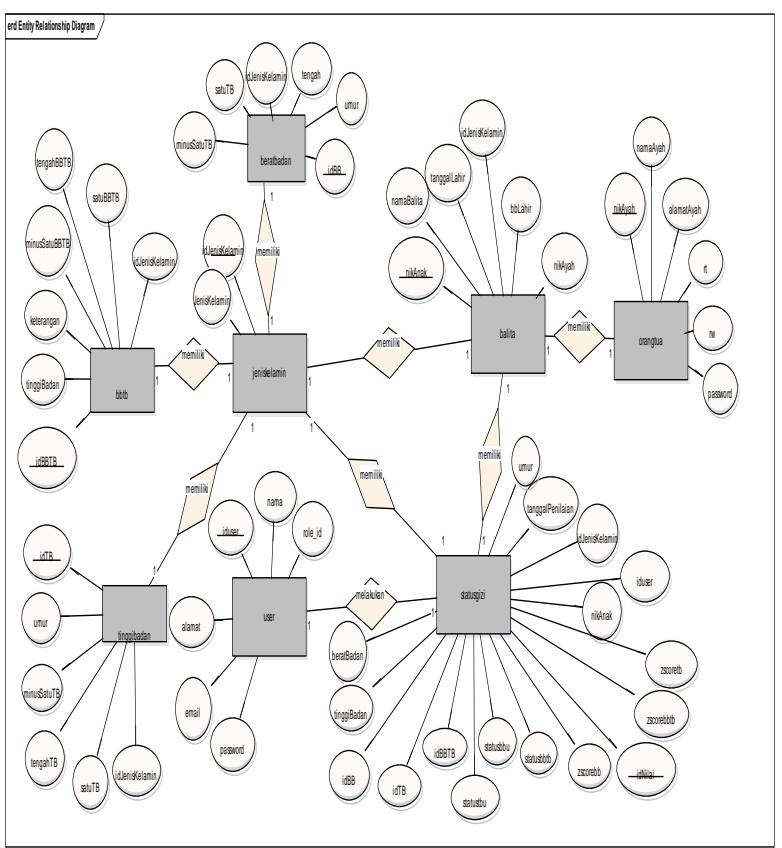

Gambar 6. Entity Relation Diagram

Entity Relation Diagram pada penelitian ini memiliki delapan entity yaitu user, balita, orangtua, status gizi, jenis kelamin, bbtb, berat badan dan tinggi badan. Relasi dari setiap entity yaitu one to one terhadap entity lain.

Berikut adalah tampilan dari sistem informasi pencatatan gizi balita dengan metode forward chaining.

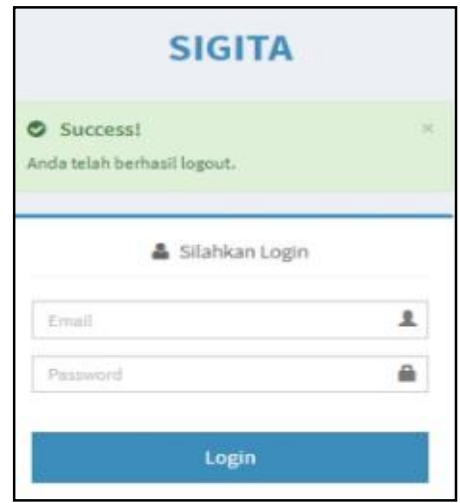

Gambar 7. Form Login

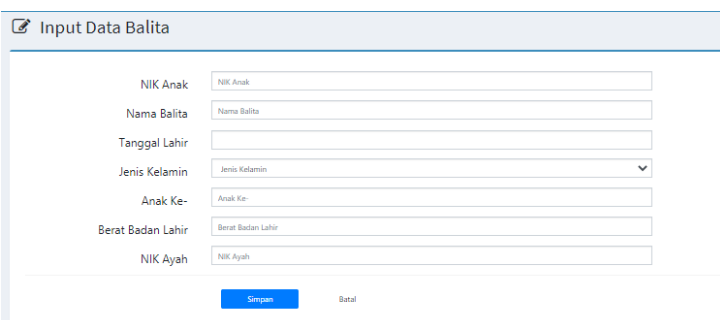

Gambar 8. Form Data Balita

Pada form data balita, user menginputkan NIK anak, nama balita, tanggal lahir, jenis kelamin, anak ke-, berat badan lahir dan NIK ayah.

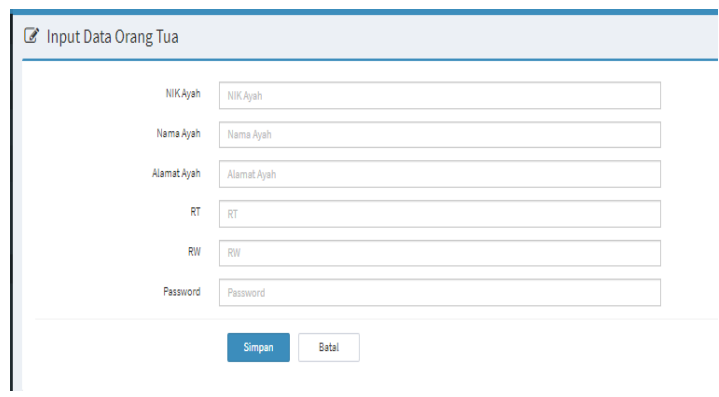

Gambar 9. Form Data Orang Tua

Pada form data orang tua, user menginputkan NIK ayah, nama ayah, alamat, RT, RW danpassword.

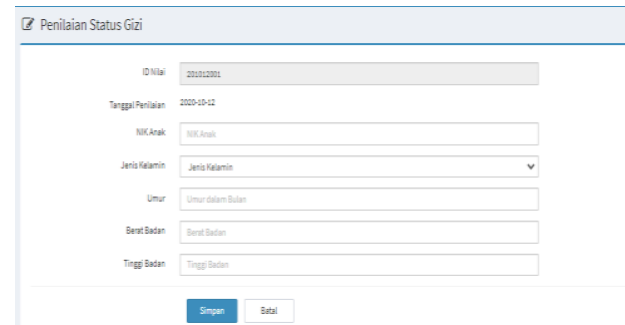

Gambar 10. Form PenilaianStatus Gizi

Pada form penilaian status gizi, id nilai dan tanggal otomatis. User hanya menginputkan NIK anak, jenis kelamin, umur, berat badan dan tinggi badan. 


\section{d. Pembuatan Code Program}

Pada tahapan ini yaitu program komputer sesuai dengan desain yang telah dibuat pada tahapan sebelumnya (Sukamto \& Shalahuddin, 2018). Pada penelitian ini menggunakan bahasa pemrograman PHP, Java Script,dan HTML.

e. Pengujian

Pada penelitian ini menggunakan Blackbox testing sebagai pengujiannya. Berikut adalah tabel blackbox testing:

Tabel 3. Blackbox Testing

\begin{tabular}{|c|c|c|c|c|c|}
\hline No & $\begin{array}{l}\text { Skenario } \\
\text { Pengujia } \\
\text { n }\end{array}$ & $\begin{array}{l}\text { Test } \\
\text { Case }\end{array}$ & $\begin{array}{l}\text { Hasil yang } \\
\text { diharapka } \\
\text { n }\end{array}$ & $\begin{array}{l}\text { Hasil } \\
\text { Peng } \\
\text { ujian } \\
\end{array}$ & $\begin{array}{l}\text { Kesi } \\
\text { mp } \\
\text { ulan } \\
\end{array}$ \\
\hline 1 & $\begin{array}{l}\text { Email } \\
\text { dan } \\
\text { password } \\
\text { tidak } \\
\text { terisi }\end{array}$ & $\begin{array}{l}\text { Email } \\
: \\
\text { (koson } \\
\text { g) } \\
\text { Passw } \\
\text { ord : } \\
\text { (Koso } \\
\text { ng) }\end{array}$ & $\begin{array}{l}\text { Sistem } \\
\text { akan } \\
\text { menolak } \\
\text { untuk } \\
\text { login dan } \\
\text { menampi } \\
\text { lkan } \\
\text { pesan } \\
\text { "Please } \\
\text { fill out } \\
\text { this } \\
\text { field." }\end{array}$ & $\begin{array}{l}\text { Sesuai } \\
\text { Harapan }\end{array}$ & $\begin{array}{l}\text { Vali } \\
\text { d }\end{array}$ \\
\hline 2 & $\begin{array}{l}\text { Email } \\
\text { benar } \\
\text { dan } \\
\text { password } \\
\text { salah }\end{array}$ & $\begin{array}{l}\text { Email } \\
: \\
\text { (rnr.re } \\
\text { tno@g } \\
\text { mail.c } \\
\text { om) } \\
\text { Passw } \\
\text { ord : } \\
(* * * * \\
*)\end{array}$ & $\begin{array}{l}\text { Sistem } \\
\text { akan } \\
\text { menolak } \\
\text { untuk } \\
\text { login dan } \\
\text { menampi } \\
\text { lkan } \\
\text { pesan } \\
\text { "Email } \\
\text { atau } \\
\text { password } \\
\text { salah, } \\
\text { cek } \\
\text { kembali } \\
\text { email } \\
\text { dan } \\
\text { password } \\
\text { anda" } \\
\end{array}$ & $\begin{array}{l}\text { Sesuai } \\
\text { Harapan }\end{array}$ & $\begin{array}{l}\text { Vali } \\
\text { d }\end{array}$ \\
\hline 3 & $\begin{array}{l}\text { Email } \\
\text { salah dan } \\
\text { paswwor } \\
\text { d benar }\end{array}$ & $\begin{array}{l}\text { Email } \\
: \\
\text { (retno } \\
\text { @ gma } \\
\text { il.com } \\
\text { ) } \\
\text { Passw } \\
\text { ord : }\end{array}$ & $\begin{array}{l}\text { Sistem } \\
\text { akan } \\
\text { menolak } \\
\text { untuk } \\
\text { login dan } \\
\text { menampi } \\
\text { lkan } \\
\text { pesan }\end{array}$ & $\begin{array}{l}\text { Sesuai } \\
\text { Harapan }\end{array}$ & $\begin{array}{l}\text { Vali } \\
\text { d }\end{array}$ \\
\hline
\end{tabular}

\begin{tabular}{|c|c|c|c|c|c|}
\hline & & $(* * * *)$ & $\begin{array}{l}\text { "Email } \\
\text { atau } \\
\text { password } \\
\text { salah, } \\
\text { cek } \\
\text { kembali } \\
\text { email } \\
\text { dan } \\
\text { password } \\
\text { anda" }\end{array}$ & & \\
\hline 4 & $\begin{array}{l}\text { Email } \\
\text { dan } \\
\text { password } \\
\text { benar }\end{array}$ & $\begin{array}{l}\text { Email } \\
: \\
\text { (rnr.re } \\
\text { tno@g } \\
\text { mail.c } \\
\text { om) } \\
\text { Passw } \\
\text { ord: } \\
(* * * * \\
*)\end{array}$ & $\begin{array}{l}\text { Sistem } \\
\text { akan } \\
\text { menampi } \\
\text { lkan } \\
\text { beranda }\end{array}$ & $\begin{array}{l}\text { Sesuai } \\
\text { Harapan }\end{array}$ & $\begin{array}{l}\text { Vali } \\
\text { d }\end{array}$ \\
\hline
\end{tabular}

\section{Conclusions}

Pada penelitian ini dapat diambil kesimpulan bahwa sistem informasi pencatatan gizi balita sangat membantu pengurus posyandu yang meliputi data penimbangan balita sehingga dapat ditindak lanjuti jika ada balita berada di Bawah Garis Merah. Metode Forward Chaining dapat diterapkan pada sistem informasi pencatatan gizi balita dengan menggabungkan tabel antropometri sehingga menghasilkan standar gizi balita sesuai dengan buku kementerian kesehatan. Kekurangan pada aplikasi ini adalah aplikasi ini tidak menyediakan grafik untuk memudahkan membaca status gizi. Saran untuk penelitian selanjutnya yaitu untuk dibuatkan grafik yang memudahkan membaca status gizi tanpa harus melihat laporan penilaian status gizi. 


\section{References}

Astuti, I., Sutarno, H., \& Rasim. (2017). The Expert System of Children's Digestive Tract Diseases Diagnostic Using Combination of Forward Chaining and Certainty Factor Methods. International Conference on Science in Information Technology, 608-612.

https://doi.org/10.1109/ICSITech.2017. 8257185

Devi, M. (2010). Analisis Faktor-Faktor Yang Berpengaruh Terhadap Status Gizi Balita di Pedesaan. Teknologi Dan Kejuruan, 33(2), 183-192. https://doi.org/10.1590/s010120611999000300022

Effendi, R., Roslidar, \& Dawood, R. (2015). Rancang Bangun Sistem Informasi Rekam Medik Posyandu Berbasis Komputasi Awan. Seminar Nasional Dan Expo Teknik Elektro.

Firmansyah, R. I., Risanty, R. D., \& Mujiastuti, R. (2002). Aplikasi Skrining Gizi Anak Mengguankan Metode Forward Chaining. Encyclopedia of Psychotherapy, 823827. https://doi.org/10.1016/b0-12343010-0/00099-4

Fitri, M. O. (2017). Aplikasi Monitoring Perkembangan Status Gizi Anak dan Balita Secara Digital Dengan Metode Antropometri Berbasis Android. Instek, 2(2), 140-149. https://doi.org/10.2473/amnt.v2i4.2018 .325-331

Hayadi, B. H. (2015). Sistem Pakar. Riau: Deepublish.

Jakarta, B. P. dan P. D. K. P. D. (2018). Profil Kesehatan Provinsi DKI Jakarta Tahun 2018.

Kemenkes, D. (2011). Keputusan Menteri Kesehatan RI tentang Standar Antropometri Penilaian Status Gizi Anak. Standar Antropometri Penilaian Status Gizi Anak.

Mulyani, E. D. S., Erwandi, D., \& Aryanti, N. (2015). Sistem Pakar Diagnosis Gizi Buruk Pada Balita Menggunakan
Metode Forward Chaining di Puskesmas Tinewati. Konferensi Nasional Sistem \& Informatika 2015, 329-334.

Nuraeni, E. en, Wajhillah, R., \& Pribadi, D. (2014). Sistem Informasi Pemantauan Tumbuh Kembang Balita Pada Posyandu Menggunakan Metode Z Score Berbasis Web (Studi Kasus : Posyandu Durian 8 Kel. Subangjaya Kota Sukabumi). Seminar Nasional Inovasi Dan Tren (SNIT), 130-135.

Pratama, S. (2016). Penerapan Sistem Informasi Posyandu Mawar Kelurahan SImpang Empat. Technologia, 7(4), 237-244.

Ratnawati, M., Probowati, R., Prihatini, M. S., Pawiono, P., \& Pujiani, P. (2020). Self Efficacy Ibu dalam Pemberian Makanan pada Balita BGM (Bawah Garis Merah) di Puskesmas Mayangan Kecamatan Jogoroto Jombang. Journal of Community Engagement in Health, $3(1)$, 29-32. https://doi.org/10.30994/jceh.v3i1.28

Rosnelly, R. (2011). Sistem Pakar Konsep dan Teori. Medan: CV. Andi Offset.

Setyowati, M., \& Astuti, R. (2015). Pemetaan Status Gizi Balita Dalam Mendukung Keberhasilan Pencapaian Millenium Development Goals (MDGs). Jurnal Kesehatan Masyarakat, 10(2), 110-121. Retrieved from https://journal.unnes.ac.id/nju/index.ph p/kemas/article/view/3371

Shofi, I. M., Wardhani, L. K., \& Anisa, G. (2016). Android Application For Diagnosing General Symptoms of Disease Using Forward Chaining Method. International Conference on Cyber and IT Service Management, 17.

Simorangkir, L., Kahar, N., \& Simatupang, D. S. (2015). Sistem Pakar Untuk Mendiagnosa Gizi Buruk Pada Balita Menggunakan Metode Forward Chaining. Media Sisfo, 9(1), 240-247.

Sukamto, R. A., \& Shalahuddin, M. (2018). 
Rekaya Perangkat Lunak. Bandung: Informatika Bandung.

Sunarya, I. M. G., Wirawan, I. M. A., \& Sukendry, N. M. N. (2017). Sistem Pakar Pendeteksi Gizi Balita dan Alternatif Pencegahan Menggunakan
Metode Certainty Factor. Jurnal Nasional Pendidikan Teknik Informatika (JANAPATI), 6(1), 50. https://doi.org/10.23887/janapati.v6il. 9929 